\title{
Pola Pengkaderan Ulama di Sulawesi Selatan (Studi pada Program Ma'had Aly Pondok Pesantren As'adiyah Sengkang Kabupaten Wajo)
}

\author{
Idham \\ Balai Penelitian dan Pengembangan Agama Makassar \\ idham.litbangmks@gmail.com
}

\begin{abstract}
This article aims to elaborate the pattern of regeneration of Islamic scholars (ulama) in South Sulawesi by focusing on the study of Ma'had Aly As'adiyah Sengkang Wajo. In the search, a qualitative approach was used. Data collecting was done through interviews, observation, literature study and documentation. The results of the research indicate that the regeneration of Islamic scholars in South Sulawesi had been long conducted in some Pondok Pesantren (Islamic Boarding Schools). This study finds out that the regeneration of Islamic scholars was provided with a certain medium in a special program. The existence of Pondok Pesantren As'adiyah Sengkang by implementing the regeneration of Islamic scholars through Ma'had Aly caused Pondok Pesantren As'adiyah Sengkang to be one of 13 organizers of Ma'had Aly program that was given an operational license by the Ministry of Religious Affairs of the Republic of Indonesia.
\end{abstract}

\begin{abstract}
Abstrak
Artikel bertujuan untuk mengelaborasi pola regenerasi ulama di Sulawesi Selatan dengan memusatkan perhatian pada studi Ma'had Aly As'adiyah Sengkang Wajo. Dalam pencarian, digunakan pendekatan kualitatif. Pengumpulan data dilakukan melalui wawancara, observasi, studi pustaka dan dokumentasi. Hasil penelitian menunjukkan bahwa regenerasi ulama Islam di Sulawesi Selatan telah lama dilakukan di beberapa Pondok Pesantren. Studi ini menemukan bahwa regenerasi ulama Islam diberikan dengan media tertentu dalam program khusus. Keberadaan Pondok Pesantren As'adiyah Sengkang dengan menerapkan regenerasi ulama Islam melalui Ma'had Aly menyebabkan Pondok Pesantren As'adiyah Sengkang menjadi salah satu dari 13 penyelenggara program Ma'had Aly yang diberi izin operasional oleh Menteri Agama Republik Indonesia.
\end{abstract}

Keywords: Ma'had Aly, Pondok Pesantren, Pendidikan Pesantren 


\section{A. Pendahuluan}

Umat Islam di Indonesia kini dapat berbangga karena memiliki satuan pendidikan keagamaan Islam pada jenjang pendidikan tinggi yang populer dengan nama Ma'had Aly. Hal ini lantaran keberadaannya telah diresmikan Menteri Agama Republik Indonesia, Lukman Hakim Saifuddin pada Senin (30/05/2016) di Pondok Pesantren Tebuireng, Jombang Jawa Timur). Sesuai dengan Penjelasan dalam Peraturan Menteri Agama (PMA) Nomor 71 Tahun 2015, yang dimaksud dengan Ma'had Aly adalah Perguruan Tinggi Keagamaan Islam yang menyelenggarakan pendidikan nakademik dalam bidang penguasaan ilmu agama Islam (Tafaqqhu Fiddin) berbasis kitab kuning yang diselenggarakan oleh dan berada di pesantren. ${ }^{1}$ Ma'had Aly adalah wujud pelembagaan sistemik tradisi intelektual pesantren tingkat tinggi yang keberadaannya melekat pada pendidikan pesantren. Secara kelembagaan, posisi Ma'had Aly adalah jenjang Pendidikan Tinggi Keagamaan pada jalur Pendidikan Diniyah Formal.

Jauh sebelum lahirnya PMA 71/2015 tersebut, di Sulawesi Selatan telah diselenggarakan program Ma'had Aly di beberapa Pondok Pesantren. Ma'had Aly tersebut adalah program khusus yang diadakan oleh Pondok Pesantren dalam rangka mengantisipasi keprihatinan akan langkanya ulama. Kompleksnya tugas dan peran ulama semata-mata karena pentingnya posisi itu di mata umat. Pada masa Khulafarur Rasyidin, tidak ada pemisahan antara orang yang memiliki pengetahuan, ilmu kealaman, dan pemimpin politik praktis. Para sahabat nabi umumnya memiliki pengetahuan keagamaan, pengetahuan kealaman dan sekaligus juga pelaku-pelaku politik praktis (ensiklopedi, 1994: 120). Keadaan ini sekaligus menunjukkan bahwa para sahabat adalah para ulama yang memikul tugas dan tanggung jawab keumatan secara luas, sebagai panutan umat dan sebagai pemimpin dalam segala hal. ${ }^{2}$

Figur ulama yang multi fungsi bergeser sejak pemerintahan Bani Umayyah dan sesudahnya sampai sekarang. Sosok ulama seperti yang digambarkan di atas susah ditemukan. Di Indonesia, istilah ulama atau

\footnotetext{
${ }^{1}$ https://www.nu.or.id/post/read/68643/mahad-aly-sebagai-pusat-unggulan, diunduh tanggal 25 September 2016

${ }^{2}$ Abd. Malik. Studi Tentang Efektifitas Pendidikan Kader Ulama (PKU) Terhadap Kaderisasi Ulama di Sulawesi selatan (tesis belum terbit). Makassar: Program Pascasarjana Universitas Muslim Indonesia, (2001) h. 2
} 
alim ulama yang semula sebagai bentuk jamak berubah pengertiannya menjadi bentuk tunggal. Pengertian ulama juga menjadi lebih sempit, karena diartikan sebagai orang yang memiliki ilmu keagamaan dalam bidang fiqhi, sehingga ulama identik dengan fuqaha, bahkan pengertian awam sehari-hari, ulama adalah fuqaha dalam ibadah saja. Sempitnya pengertian ulama mendorong pada terbatasnya ruang kiprah ulama itu sendiri. Sehingga ulama di samping kurang berperan luas di bidang sosial, juga keberadaannyaa semakin langka. Kelangkaan ulama ini kemudian menimbulkan keprihatinan banyak kalangan, terutama terhadap kemungkinan hilangnya figur-figur ulama yang mampu menjadi panutan umat, pembimbing mereka untuk keluar dari persoalan kehidupan yang sangat pelik dan senjang dari pengaruh dunia yang global dan kemaksiatan yang merajalela. ${ }^{3}$

Kelangkaan ulama tersebut banyak disikapi oleh lembagalembaga pendidikan keagamaan seperti pondok pesantren dan organisasiorganisasi sosial keagamaan, seperti NU, Muhammadiyah, Darud Da'wal wal Irsyad, As'adiyah, Wahdah Islamiyah, dan MUI Sulawesi Selatan serta beberapa Perguruan Tinggi di Sulawesi Selatan. Muncul kegiatan yang berorientasi pada upaya pembinaan calon-calon ulama atau kaderisasi ulama sebagai warasatul anbiya (pemaris para nabi). Di lingkungan pondok pesantren, upaya pembinaan calon-calon ulama dilakukan melalui kegiatan kepesantrenan, seperti takhassus, sedangkan di lingkungan sosial keagamaan dilakukan dalam bentuk pelatihanpelatihan berkala. Ada beberapa lembaga penyelenggara Ma'had Aly di Sulawesi Selatan, baik yang masih berlanjut maupun yang sudah vakum, antara lain: 1) Haiatut Takaful, 2) Ma'had Aly DDI Parepare, 3) Ma'had Aly As'adiyah Sengkang, 4) Ma'had Aly Yasrib Soppeng, 5) Ma'had Aly DDI Barru, 6) Ma'had Aly UIN Alauddin Makassar, 7) Ma'had Aly Wahdah Islamiyah (STIBA), 8) Ma'had Aly Universitas Muhammadiyah (PUT, Pengkaderan Ulama Tarjih), dan 9) Pendidikan Kader Ulama (PKU) oleh MUI Sulawesi Selatan.

Dari Sembilan ma'had Aly tersebut di atas, ada empat yang sudah vakum yakni Ma'had Aly Haiatut Takaful, Ma'had Aly Parepare, Ma'had Aly Yasrib, dan Ma'had Aly yang diselenggarakan MUI Sulawesi Selatan yang bertempat di Masjid Raya Makassar. Fokus

\footnotetext{
${ }^{3}$ Abd. Malik. Studi Tentang Efektifitas Pendidikan Kader Ulama (PKU) Terhadap Kaderisasi Ulama di Sulawesi selatan (tesis belum terbit). Makassar: Program Pascasarjana Universitas Muslim Indonesia, (2001) h. 3
} 
tulisan ini adalah Ma'had Aly As'adiyah Sengkang, yang sejak berdirinya masih berjalan sampai sekarang, bahkan Ma'had Aly As'adiyah Sengkang adalah salah satu dari 13 Ma'had Aly yang sudah diakui/ditetapkan izin operasionalnya oleh Kementerian Agama, dan menjadi satu-satunya Ma'had Aly yang diakui di Indonesia bagian timur.

Berdasarkan pada latar belakang di atas, permasalahan yang diangkat dalam tulisan ini, adalah bagaimana pengkaderan ulama yang diselenggarakan oleh Ma'had Aly As'adiyah Sengkang Kabupaten Wajo? Permasalahan tersebut dijabarkan dalam pertanyaan: pertama Bagaimana pola pembinaan yang diterapkan pada Ma'had Aly Sengkang Kabupaten Wajo? Kedua Faktor apa saja yang mendukung dan menghambat terselenggaranya Ma'had Aly Sengkang Kabupaten Wajo?

Tujuan tulisan ini untuk mengungkap pola pembinaan yang diterapkan oleh Ma'had Aly Sengkang Kabupaten Wajo, selain itu untuk mengetahui faktor-faktor yang mendukung dan menghambat terselenggaranya Ma'had Aly Sengkang Kabupaten Wajo.

Penelitian ini adalah penelitian deskriptif kualitatif. Pengumpulan data lapangan melalui: wawancara, observasi, studi pustaka, dan dokumentasi. Sebagai penelitian kualitatif, maka peneliti menjadi instrumen utama.4 Analisis data dilakukan sejak pengumpulan data sampai pelaporan dengan menggunakan analisis deskriptif kualitatif.

Ada beberapa penelitian maupun tulisan dalam bentuk buku yang membahas tentang pesantren, khususnya yang berkenaan langsung dengan Pondok Pesantren As'adiyah. Yang paling mutakhir, ada tiga disertasi, yang pertama (Halim, 2015), ${ }^{5}$ tulisan ini membahas tentang tradisi As'adiyah dalam merekonstruksi dan mereproduksi ulama di Sulawesi Selatan, tulisan yang kedua (Pasanreseng, 2015) ${ }^{6}$ yang mengkaji efektifitas dakwah Pondok Pesantren As'adiyah, dan ketiga (Muchsin, 2014) ${ }^{7}$ yang mengkaji tentang manhaj fiqhi pesantren

\footnotetext{
${ }^{4}$ Sugiyono. Metode Penelitian Pendidikan (Pendekatan Kualitatif, Kuantitatif, dan R \& D. Bandung: Alfabeta, (2010) h. 305.

${ }^{5}$ Halim, Wahyuddin. As'adiyah Traditions: The Construcion and Reproduction of Religious Authority in Contemprary South Sulawesi (Disertasi, belum terbit). Australia: Australian National University. (2015)

6 Pasanreseng, Muh. Yunus.. Efektifitas Dakwah Pondok Pesantren As'adiyah (Disertasi, belum terbit). Makassar: Pascasarjana UIN Alauddin Makassar. 2015

${ }^{7}$ Muchsin, Agus. Konstruksi Kaderisasi Ulama Pondok Pesantren As'adiyah Sengkang dan Pondok Pesantren Darud Dakwah wal Irsyad Mangkoso: Tinjauan Terhadap
} 
As'adiyah Sengkang dan DDI Mangkoso, Barru. Selain itu, ada beberapa tulisan yang secara khusus membahas sosok pendiri As'adiyah, Gurutta Muhammad As'ad dan perjuangannya dalam dakwah, pendidikan dan Pembaharuan Islam di Wajo, antara lain: Walinga (1981), ${ }^{8}$ Bisfain (1984), ${ }^{9}$ Ismail (1989), ${ }^{10}$ Manguluan (1989), ${ }^{11}$ Bruinessen (1998), ${ }^{12}$ Hamka (2009), ${ }^{13}$ Arif (2003), ${ }^{14}$ Surur (2011). ${ }^{15}$ Tulisan yang lain membahas tentang pesantren As'adiyah dalam pembaharuan pendidikan Islam di Sulawesi Selatan, antara lain: Abu Hamid (1983), ${ }^{16}$ Al Bone (1986), ${ }^{17}$ Rama (2000), ${ }^{18}$ Rahman Halim (2008), ${ }^{19}$ Maratan (1978), ${ }^{20}$

Manhaj Fikih Pesanttren (disertasi, belum Terbit). Makassar: Program Pascasarjana UIN Alauddin Makassar. 2014

${ }^{8}$ Muh. Hatta Walinga.. Kiyai Haji Muhammad As'ad Hidup dan Perjuangannya (Skripsi). Ujungpandang: Fakultas Adab IAIN Alauddin Makassar. 1981

${ }^{9}$ Bisfain.. K.H. Muhammad As'ad: Peranannya Dalam dakwah di Daerah Wajo (Skripsi). Ujungpandang: Fakultas Ushuluddin IAIN Alauddin Makassar. 1984

${ }^{10}$ Daud Ismail.. Al Ta'rifu bi al 'alimi al 'Allamah al Haji Muhammad As'ad al Bugisy. Ujungpandang: Bintang Selatan 1989

${ }^{11}$ Hamzah Manguluan.. Ana wa Syaekhi (Riwayatku dan Mahaguruku). Sengkang: ttp. 1989

${ }^{12}$ Martin van Bruinessen.. Muhammad As'ad Bugis (Wajo, South Sulawesi, Indonesia 1907-1953), dalam Dictionnaire Biographigue des Savants et Grande Figures du Munde Musulman Periperique, du XIXe siècle a nos jours, Fasc, No. 2. Faris: CNRS-EHESS. 1998

${ }^{13}$ Zainuddin Hamka. Corak Pemikiran Keagamaan Gurutta H. Muh. As'ad Al Bugisi. Jakarta: Departemen Agama RI Badan Litbang dan Diklat Pulitbang Lektur dan Khazanah Lektur Keagamaan. 2009

${ }^{14}$ Fahmi Arif. K.H. Muhammad As'ad Al Bugisi, dalam Mastuki HS dan M. Ishom El Saha (eds). Intelektualisme Pesantren Potret Tokoh dan Cakrawala Pemikiran si Era Perkembangan Pesantren.( Jakarta: Diva Pustaka. 2003)

${ }^{15}$ M. Bunyamin Yusuf Surur. K.H. As'ad bin Abd. Rasyid al Bugisy:Perintis Ulama Huffazh di Sulawesi Selatan (1907-1952), dalam Muhammad Shohib dan M. Bunyamin Surur (eds). Para Penjaga Al Qur'an: Biografi Huffaz Al-Qur'an di Nusantara. Jakarta: Lanjnah Pentashihan Mushaf Al Qur'an Badan Litbang dan Diklat Kementerian Agama RI. 2011

${ }^{16}$ Abu Hamid. 1983. Sistem Pendidikan Madrasah dan Pesantren di Sulawesi Selatan, dalam Taufik Abdullah, Agama dan Perubahan Sosial, Jakarta: Rajawali Press .

${ }^{17}$ Abd. Aziz al Bone.. Lembaga Pendidikan Islam di Sulawesi Selatan (Studi Kasus di Perguruan As'adiyah Sengkang. Jakarta: Yayasan ilmu-Ilmu Sosial. 1986

${ }^{18}$ Bahaking Rama.. Pembaharuan Pendidikan Pesantren As'adiyah Sengkang-Wajo Sulawesi Sealatan. Disertasi. (Jakarta: Program Pascasarjana IAIN Syarif Hidayatullah Jakarta. 2000) 
Pasanreseng (1992), ${ }^{21}$ Bosra (2008), ${ }^{22}$ Ahmad Rahman (2010), ${ }^{23}$ dan lain-lain.

\section{B. Wajo: Lokus Daerah Penelitian}

Penyebaran Islam ke berbagai daerah di Nusantara tidak berlangsung secara bersamaan. Kedatangan Islam di Sulawesi Selatan, misalnya, agak terlambat bila dibandingkan dengan daerah lainnya di Indonesia, terutama Sumatera dan Jawa. ${ }^{24}$ di Wajo sendiri, Agama Islam dinyatakan resmi diterima masyarakat Wajo pasa hari Selasa 15 Safar $1020 \mathrm{H}$ atau $6 \mathrm{Mei} 1610 \mathrm{M}^{25}$ Adapun raja yang pertama kali menerima resmi agama Islam di Wajo adalah Arung Matoa Wajo (raja Wajo) ke 12, Lasangkuru Patau Mulajaji yang bergelar Sultan Abdul Rahman. Ia menyatakan diri masuk Islam dan mengucap syahadatain di depan Sultan Alauddin (Raja Gowa) di Kampung Topaccedo-Tosora. ${ }^{26}$

Masuk dan berkembangnya agama Islam di berbagai kerajaan atau daerah bekas kerajaan di kawasan Sulawesi Selatan, khususya di daerah Wajo baik secara damai maupun dengan jalan kekerasan, telah membawa warna baru dalam kehidupan masyarakat. Hal ini dapat dilihat

\footnotetext{
${ }^{19}$ Abdul Rahman Halim. Kebijakan dan Partisipasi Masyarakat (Studi Terhadap Perspektif Pembinaan Madrasah Swasta di Sulawesi Selatan (Disertasi, belum terbit). Yogyakarta: Pascasarjana UIN Sunan Kalijaga Yogyakarta. 2008

${ }^{20}$ Muh. Yunus Maratan. Sejarah Singkat Berdirinya Perguruan Madrasah As'adiyah, dalam majalah Bulanan: Safari Dakwah, No. 15 Tahun II. 1978

21 Muh. Yunus Pasanreseng.. Sejarah Lahir dan Prtumbuhan Pondok Pesantren As'adiyah Sengkang. Sengkang: Pengurus Besar As'adiyah. 1992

${ }^{22}$ Mustari Bosra. Tuan Guru, Anrong Guru dan Daeng Guru: Gerakan Islam di Sulawesi Selatan 1014-1942. (Makassar: La Galigo Press. 2006)

${ }^{23}$ Ahmad Rahman (ed). Inventarisasi Karya Ulama di Lembaga Pendidikan Keagamaan. Jakarta: Puslitbang nLektur Keagamaan Balitbang dan Diklat Keagamaan Kementerian Agama RI. 2010

${ }^{24}$ Bahaking Rama. 2000. Pembaharuan Pendidikan Pesantren As'adiyah SengkangWajo Sulawesi Sealatan. Disertasi. Jakarta: Program Pascasarjana IAIN Syarif Hidayatullah Jakarta, h. 83.

${ }^{25}$ Sumange Alam. Masuknya Islam di Wajo. Sengkang: Kantor Departemen Pendidikan dan Kebudayaan Kabupaten Wajo (Hasil Penelitian, belum terbit), h. 9, dan lihat juga Abdul Karim Hafid. 1997. K.H. Muhammad As'ad dan Peraannnya Terhadap Pemurnian Aqidah Islamiyah di Wajo. Sengkang: Sekolah Tinggi Islam As'adiyah Sengkang, 37. 1982

${ }^{26}$ Bahaking Rama. Pembaharuan Pendidikan Pesantren As'adiyah Sengkang-Wajo Sulawesi Sealatan. Disertasi. (Jakarta: Program Pascasarjana IAIN Syarif Hidayatullah Jakarta, h. 89. 2000)
} 
pada pola-pola sosial dan kedudukan yang mengalami perubahan, meskipun lambat. Ajaran-ajaran agama yang bersumber dari kitab samawi dan kebiasaan-kebiasaan lama yang merupakan adat, tetap dibenarkan dalam Islam, sepanjang tidak bertentangan dengan syariat Islam. $^{27}$

Hal tersebut dapat dipahami karena kedatangan awal Islam, hanyalah merupakan pengenalan awal. Penekanannya adalah pada tauhid, keimanan kepada Allah. ${ }^{28}$ Proses selanjutnya tidak diikuti dengan pendalaman ajaran, baik pemahaman maupun praktek. Selain itu, mereka menerima Islam bukan lahir dari kesadaran sendiri, tetapi berdasarkan ketaatan kepada raja atau penguasa. Hal itu disebabkan karena agama dikembangkan melalui raja-raja yang berkuasa, sehingga kehidupan beragama masih bersifat sinkritisme, yaitu praktek ajaran agama Islam yang perwujudannya banyak berbaur dengan tradisi dan kepercayaan asli nenek moyang. ${ }^{29}$

Sejak masuknya Islam di Wajo (awal abad ke-17) terlihat adanya harmonisasi beberapa kerajaan, khususnya di Sulawesi Selatan menjadikan batas-batas kerajaan menjadi kabur atas semangat persatuan umat Islam yang memakin meningkat. Diperkuat lagi karena semua wilayah Sulawesi Selatan berada di bawah kekuasaan dan kedaulatan pemerintah Belanda. Pada bulan November 1846, daerah Sulawesi Selatan menjadi satu kesatuan administratif yang memungkinkan penduduknya dapat bergerak ke seluruh daerah dan keluar dari Sulawesi Selatan. Itulah sebabnya banyak orang-orang Sulawesi Selatan berangkat ke Mekah untuk melakukan ibadah haji. Di antara mereka yang melakukan ibadah haji tersebut, ada yang tinggal sementara untuk menuntut ilmu, bahkan ada yang mukim, menjadi penduduk Arab Saudi. Sebaliknya Sulawesi Selatan sangat terbuka bagi orang luar, menerima pendatang dari luar, termasuk para pedagang Arab, ulama-ulama dari

\footnotetext{
${ }^{27}$ Suradi Mappangara dan Irwan Abbas. Sejarah Islam di Sulawesi Selatan. (Makassar: Lamacca Press, 2003)h. 176.

${ }^{28}$ Mattulada. Islam di Sulawesi Selatan, dalam Taufik Abdullah (ed). Agama dan Perubahan Sosial. (Jakarta: Rajawali, 1983) h 250.

29 Mukhlis.. Agama dan Realitas Sosial. Ujungpandang: Lephas.; Ali, Fachri dan Bachtiar Effendy. 1986: Merambah Jalan Baru Islam. Bandung: Mizan, h. 37; Zainuddin Hamka. 2009. Corak Pemikiran Keagamaan Gurutta H. Muh. As'ad Al Bugisi. (Jakarta: Departemen Agama RI Badan Litbang dan Diklat Pulitbang Lektur dan Khazanah Lektur Keagamaan, 1987) h. 9 .
} 
pulau Jawa, Sumatera dan sebagainya untuk mengajarkan ilmu-ilmu agama. ${ }^{30}$

Keterbukaan orang Sulawesi Selatan untuk menerima orangorang luar berlangsung sampai sekarang. Itulah sebabnya pada tahun 1926, atas inisiatif Mansyur al Yamani, seorang Arab, pedagang batik dari Surabaya bersama K.H. Abdullah Dahlan membentuk Gerakan Islam Muhammadiyah di Makassar. K.H. Abdullah Dahlan sebagai ketua dan Mansyur al Yamani sebagai wakil ketua, serta kawan-kawannya bekerja keras memberantas kemusyrikan, bid'ah, khurafat, dan tahyul. Dua tahun kemudian, tetaptnya tanggal 15 Juli $1928 \mathrm{M}$, organisasi ini membentuk cabang di Wajo yang dipelopori oleh Syekh Ahmad Balahmar (yang kemudian menjadi Kadhi Wajo) setelah mengadakan pertemuan dengan pengurus Muhammadiyah Makassar. ${ }^{31}$ Adapun yang menjadi pengurus Muhammadiyah di Wajo adalah $\mathrm{H}$. Andi Muri sebagai ketua dan Andi Juranga sebagai Wakil Ketua. ${ }^{32}$ Itulah sebabnya Konfrensi Muhammadiyah se-Sulawesi Selatan di Pusatkan di Sengkang-Wajo pada tanggal 20 Mei 1929.

Sebelum kedatangan Muhammadiyah di Wajo, sudah ada ulama yang mendahuluinya, yakni H. Makkatu. Beliau adalah seorang ulama putra Wajo yang telah menuntut ilmu di Mekah. Dan sekembalinya dari Mekah ia bermukim di Tosora-Wajo, di sana beliau mengadakan pengajian dan selanjutnya mengadakan lembaga pendidikan Islam secara formal. ${ }^{33}$ Dengan keberadaan $\mathrm{H}$. Makkatu yang mengelola sebuah lembaga pendidikan formal dan pesantren di Tosora-Wajo, maka penyelenggaraan pendidikan mengalami perubahan dari sistem pesantren tradisional dengan cara belajar duduk bersila, tidak mengenal batas umur, tidak mengenal adanya kelas atau tingkatan, dan sebagainya ${ }^{34}$ menjadi sebuah lembaga pendidikan yang menjalankan dua sistem, yaitu sistem

\footnotetext{
${ }^{30}$ Mattulada. Islam di Sulawesi Selatan, dalam Taufik Abdullah (ed). Agama dan Perubahan Sosial. (Jakarta: Rajawali, 1983) h. 261.

${ }^{31}$ Zainuddin Hamka. Corak Pemikiran Keagamaan Gurutta H. Muh. As'ad Al Bugisi. (Jakarta: Departemen Agama RI Badan Litbang dan Diklat Pulitbang Lektur dan Khazanah Lektur Keagamaan, 2009) h. 5.

32 Rama, Bahaking. Pembaharuan Pendidikan Pesantren As'adiyah Sengkang-Wajo Sulawesi Sealatan. Disertasi. (Jakarta: Program Pascasarjana IAIN Syarif Hidayatullah Jakarta, 2000) h. 102.

${ }^{33}$ Mattulada. Islam di Sulawesi Selatan, dalam Taufik Abdullah (ed). Agama dan Perubahan Sosial. (Jakarta: Rajawali, 1983) h. 262.

34 Safwan, Mardanas dan Sutrisno Kutoyo. Sejarah Pendidikan Daerah Sulawesi Selatan. (Ujungpandang: Proyek Inventarisasi dan Dokumentasi, 1981) h. 79.
} 
pesantren dan madrasah. Sistem pesantren dengan cara belajar duduk bersila, sedangkan madrasah dengan sistem kelasikal. Namun proses belajar mengajar yang dirintis pada waktu itu belum sesempurna sebagaimana proses belajar mengajar yang dirintis oleh Muhammadiyah, yaitu K. H. Abdullah Dahlan yang membangun madrasah dan melaksanakan proses belajar mengajar dengan sistem modern, yaitu sistem klasikal, memiliki alat mobiler (kursi, meja, papan tulis, dan sebagainya). ${ }^{35}$

Antusiasnya masyarakat untuk menuntut ilmu pada saat itu tidak dibarengi dengan tenaga pengajar. Itulah sebabnya, selain usaha yang dilakukan oleh organisasi Muhammadiyah, beberapa tokoh di Wajo merasa perlu untuk menambah tenaga pengajar yang dapat memberikan bimbingan kepada umat Islam di Wajo Khususnya, dan Sulawesi sealatan pada umumnya. Maka mereka menghubungi ulama asal Wajo yang sudah lama bermukim di Mekah, seperti H. Abdul Rasyid bin guru Terru. ${ }^{36}$ salah seorang diantara putra H. Abdul Rasyid bin guru Terru adalah Gurutta H. Muhammad As'ad yang kembali ke Wajo pada tahun 1928. Adapun yang paling berjasa membawa Gurutta Muhammad As'ad ke Wajo adalah $\mathrm{H}$. Ambo Emme, yang lebih dahulu juga telah merintis pendidikan dan pengajian di rumahnya sendiri. H. Ambo Emme sendiri akhirnya menjadi ipar dari Gurutta Muhammad As'ad (salah seorang saudara Ambo Emme menikah dengan Gurutta Muhammad AS'ad). ${ }^{37}$

Hamka $^{38}$ berpendapat bahwa pembaruan pendidikan Islam di Sulawesi Selatan dimulai sejak berdirinya gerakan Islam Muhammadiyah. Adapun yang paling berjasa, khususnya di Wajo adalah dua ulama besar, yakni K.H. Abdullah Dahlan dan Gurutta Muhammad As'ad. Keduanya mempunyai latar belakang pendidikan yang sama, yakni sama-sama pernah belajar di Mekah pada masa Pemerintahan Raja Abdul Aziz dari Dinasti Ibnu Su'ud, dan kembali ke Indonesia setelah

\footnotetext{
${ }^{35}$ Abu Hamid. Sistem Pendidikan Madrasah dan Pesantren di Sulawesi Selatan, dalam Taufik Abdullah, Agama dan Perubahan Sosial, (Jakarta: Rajawali Press , 1983) h. 389.

${ }^{36}$ Bosra, Mustari. Tuan Guru, Anrong Guru dan Daeng Guru: Gerakan Islam di Sulawesi Selatan 1014-1942. (Makassar: La Galigo 2006) Press, h. 157.

${ }^{37}$ Mattulada. Islam di Sulawesi Selatan, dalam Taufik Abdullah (ed). Agama dan Perubahan Sosial. (Jakarta: Rajawali, 1983) h. 269.

${ }^{38}$ Zainuddin Hamka. Corak Pemikiran Keagamaan Gurutta H. Muh. As'ad Al Bugisi. (Jakarta: Departemen Agama RI Badan Litbang dan Diklat Pulitbang Lektur dan Khazanah Lektur Keagamaan, 2009) h. 6.
} 
mendapat pengaruh aliran pendidikan modern di Mekah (Darul Falah dan darul Ulum Mekah). Pada waktu yang bersamaan (tahun 1930-an). Muhammadiyah membangun madrasah-madrasah dengan sistem klasikal, Gurutta Muhammad As'ad menyelenggarakan pendidikan pesantren dan madrasah. Di berbagai daerah di Sulawesi Selatan berdiri pesantren, seperti yang dipimpin K.H.M. Tahir di Mandar, K.H. M. Ramli Kali Palopo di Palopo (Luwu), H. Gusain bin Umar di Bone, H. Katu di Soppeng, dan K.H.M. Thahir di Sinjai. Pesantren-pesantren tersebut kini sudah tidak ada lagi sejak tahun 1950-an, penyebabnya antara lain karena ulama pembinanya sudah meninggal dan sebahagiannya lagi terserap oleh Jawatan Agama, menjadi pegawai atau guru agama di sekolah-sekolah umum. ${ }^{39}$

\section{Pola Pengkaderan Ulama di Wajo}

Kedatangan Gurutta Muhammad As'ad di Sengkang-Wajo pada tahun 1928 langsung membuka pendidikan dengan sistem tradisional. Jadi secara historis, Upaya-upaya melahirkan kader ulama di Pesantren As'adiyah sesungguhnya telah dimulai sejak Anre Gurutta H. M. As'ad tiba di Sengkang dari Mekah pada tahun 1928. Selain giat berdakwah di sejumlah tempat di Wajo dan sekitarnya, sejak tiba di Sengkang Anre Gurutta H. M. As'ad membuka pengajian kitab (halaqah atau mangaji kitta/ magaji tudang dalam bahasa Bugis) di rumahnya untuk sejumah kecil murid (atau ana' mangaji dalam bahasa Bugis). Kabar tentang kedatangan Anre Gurutta H. M. As'ad di Sengkang dan halaqah yang diadakan di rumahnya dengan cepat menyebar hingga ke luar Wajo, bahkan ke luar Sulawesi Selatan. Segera saja jumlah ana' mangaji Anre Gurutta H. M. As'ad yang awalnya hanya belasan orang meningkat menjadi puluhan orang. Setelah kurang lebih dua tahun di Wajo, yakni bulan Mei 1930, Gurutta Muhammad As'ad mendirikan lembaga pendidikan Islam yang diberi nama Madrasal al Arabiyah al Islamiyah (disingkag MAI). ${ }^{40}$

\footnotetext{
${ }^{39}$ Hamid, Abu. Sistem Pendidikan Madrasah dan Pesantren di Sulawesi Selatan, dalam Taufik Abdullah, Agama dan Perubahan Sosial, (Jakarta: Rajawali Press, 1983) h. 388

${ }^{40}$ Pimpinan Pusat As'adiyah Buku Setengah Abd As'adiyah 1930-1980. Sengkang: Pesantren As'adiyah, h. 6; dan lihat juga Muh Yunus Pasanreseng. 1992. Sejarah Lahir dan Prtumbuhan Pondok Pesantren As'adiyah Sengkang. Sengkang: Pengurus Besar As'adiyah, 1982 h. 23
} 
Selain madrasah, pengajian dalam bentuk halaqah tetap berjalan di rumah Gurutta Muhammad As'ad. Akibatnya, halaqah di rumah Anre Gurutta H. M. As'ad tidak lagi menampung semua murid dan akhirnya harus dipindahkan ke Masjid Jami' yang lokasinya tidak jauh dari rumah Anre Gurutta H. M. As'ad (sekarang jalanan di sisi utara masjid ini dinamakan Jalan KH. M. As'ad Sengkang). Masjid Jami' dibangun untuk Anre Gurutta H. M. As'ad oleh penguasa lokal ketika itu, La Oddangpero (Arung Matoa Wajo ke- 44). Setelah jumlah murid yang datang mengikuti halaqah semakin berkembang dengan tingkatan umur dan dasar pengetahuan yang semakin beragam pula, Anre Gurutta H. M. As'ad selanjutnya mendirikan madrasah yang dinamakan Al-Madrasah Al - 'arabiyah Al-Islamiyah Wajo (disingkat MAI). Proses belajarmengajar MAI diadakan bangunan tambahan di sisi kiri, kanan dan depan Masjid Jami' yang dibangun berkat dukungan finansial dari anggota dewan penguasa tertinggi Kerajaan Wajo (Petta Ennengnge). ${ }^{4}$

Selain kegiatan yang disebutkan di atas, yang lebih penting lagi adalah bahwa Anre Gurutta H. M. As'ad juga mengadakan pengajian terbatas untuk murid-muridnya yang paling senior dan berbakat. Mereka ini dipersiapkan bukan saja untuk membantu Anre Gurutta H. M. As'ad mengajar di MAI, tetapi juga diharapkan menjadi ulama yang mandiri di masa depan. Di antara murid-muridnya yang mendapatkan didikan khusus dari Anre Gurutta H. M. As'ad yang belakangan menjadi ulama terkenal dan mendirikan pesantren adalah AGH. Abdurrahman Ambo Dalle dan AGH. Daud Ismail. Sementara itu, murid-murid angkatan kedua dari Anre Gurutta H. M. As'ad antara lain: AGH. Muhammad Yunus Martan, (Belawa-Wajo), AGH. Muhammad Abduh Pabbaja (Sidenreng) H. Muhammad Yusuf (Bone), H. Muhammad Tahir (Jalang-Wajo), H. Abbas (Sidenreng), H. Abd. Salam (Sidenreng). Adapun murid-murid angkatan ke-tiga antara lain : AGH. Muhammad Amin Nashir (Sengkang), H. Muhammad Said (Soppeng), H. M. Yusuf Surur (Pompanua-Bone), H. Galib (Sengkang), H. Harun Rasyid (Sidenreng), dan AGH. Abd. Malik Muhammad (Kelak menjadi Ketua Umum Pengurus Besar As'adiyah periode 1988-2002).

Sepeninggal Anre Gurutta H. M. As'ad pada tahun 1952, kepemimpinan MAI dilanjutkan oleh AGH. Daud Ismail (1952-1960),

\footnotetext{
${ }^{41}$ Muh. Yunus Pasanreseng. Sejarah Lahir dan Prtumbuhan Pondok Pesantren As'adiyah Sengkang. (Sengkang: Pengurus Besar As'adiyah, 1992)h. 29.
} 
salah satu muridnya yang paling senior, didampingi oleh AGH. Muhammad Yunus Martan. Dalam pertemuan para guru dan pengurus MAI di rubah menjadi Madrasah As'adiyah untuk mengenang jasa pendirinya. Pada tahun 1961, dengan alasan untuk mengembangkan pesantren di daerah asalnya di Soppeng, AGH. Daud Ismail mengundurkan diri sebagai ketua umum Madrasah As'adiyah . AGH. Muhammad Yunus Martan tampil melanjutkan kepemimpinan Madrasah As'adiyah hingga dia wafat pada tahun 1996. Di masa kepemimpinan AGH. Muhammad Yunus Martan, terbentuk Haiatut Takaful li Munadhamah al-Tarbiyah al-Islamiyah. "Haiatut Takaful ", demikian wadah ini disebut, adalah semacam forum atau badan koordinasi antar empat pondok pesantren yang didirikan oleh alumni MAI Sengkang, yaitu Pesantren As'adiyah Sengkang-Wajo, Pesantren DDI di Pare-Pare, Pesantren Yasrib di Soppeng, dan Ma'had Hadis Biru Bone. Tujuan utamanya adalah meningkatkan pendidikan dan dakwah islamiyah di Sulawesi Selatan. ${ }^{42}$

Salah satu program konkret dari Haiatut Takaful adalah pembentukan lembaga pengkaderan ulama pertama di Sulawesi Selatan yang bernama Ma'had al-Dirasah al-Islamiyah al-Ulya, yang disingkat Ma'had Aly pada tahun 1966. Tujuan lembaga ini adalah membina santri-santri berbakat untuk menjadi ulama-ulama muda dengan gelar resmi “ Kiyai Muda “ (disingkat KM) atau Gurutta Maloloe dalam bahasa Bugis. Dalam rencana awal program ini, keempat pesantren akan menjadi tuan rumah penyelenggaraan program Ma'had Aly secara bergiliran. Pesantren DDI Pare-Pare mendapat giliran pertama. Biaya penyelenggaraan pendidikan ditanggung oleh pemerintah daerah asal masing-masing mahasantri, walaupun secara formal mereka mewakili atau harus utusan keempat pesantren tersebut. ${ }^{43}$

Namun demikian, karena mengalami kesulitan finansial secara berkelanjutan, program ini hanya dapat menamatkan satu angkatan alumni di Parepare. Selanjutnya, program ini boleh dikatakan terhenti. Pada tahun 1982, Pesantren As'adiyah berinisiatif membuka kembali program Ma'had Aly Haiatut Takaful dengan menerima mahasantri

\footnotetext{
${ }^{42}$ Wawancara dengan Gurutta Suyuti (Alumni Haiatut Takaful kelas Sengkang dan pengasuh Pondok Pesantren As'adiyah Sengkang) di kediamannya pada tanggal 7 Oktober 2016.

43 Wawancara dengan Dr. Huzaimah (Alumni Haiatut Takaful kelas Sengkang dan Kepala Kantor Kementerian Agama Kabupaten Soppeng) di Kantor Kemenag Kabupaten Soppeng pada tanggal 26 September 2016.
} 
sejumlah 16 orang, yang merupakan utusan dari empat pesantren yang telah disebutkan di atas. Pada tahun ajaran 1985/1986, Ma'had Aly di Sengkang berhasil menamatkan satu angkatan alumni. Berselang lebih satu tahun kemudian, tepatnya pada tahun akademik 1988/1989, Ma'had Aly kembali menerima mahasantri baru, sebagai penyelenggara kali ini adalah pesantren Yasrib Watang Soppeng Kabupaten Soppeng. Setelah menamatkan tiga angkatan alumni, program ini pun ditutup karena berbagai faktor, terutama kekurangan dana dan tenaga pengajar.

Pada tanggal 6 Rabi'ul Awwal 1415 H/ 14 Agustus 1994 M., di bawah kepemimpinan AGH. Abd. Malik Muhammad (Periode kepengurusan 1988-2000). Yayasan As'adiyah menyelenggarakan kembali pengkaderan ulama secara mandiri, yang dinamakan al-Ma'had al-'Aly li al-Dirasat al- Islamiyah al-As'adiyah (selanjutnya disebut Ma'had Aly As'adiyah). Kurikulum, pendanaan dan proses penerimaan mahasantri Ma'had Aly sepenuhnya ditetapkan dan diupayakan oleh Yayasan As'adiyah. Pada awal pembukaannya Ma'had Aly hanya menerima mahasantri sekali dalam tiga tahun pelajaran. Dengan kata lain, hanya setelah satu angkatan menyelesaikan tiga tahun pelajaran atau tamat, baru Ma'had Aly menerima angkatan mahasantri baru. ${ }^{45}$

Pada tahun 2001, Menteri Agama RI megeluarkan Keputusan Nomor 284 Tahun 2001 yang menegaskan status Ma'had Aly sebagai lembaga pendidikan ulama tingkat tinggi, yang ditindaklanjuti dengan Keputusan Dirjen Bimbaga Islam Nomor: E/179/2001 tentang Pokokpokok Pedoman Penyelenggaraan Ma'had Aly. Dalam pedoman tersebut, disebutkan bahwa status pendidikan Ma'had Aly dapat bersifat formal dan nonformal. Jika menerapkan pola lembaga pendidikan tinggi formal maka kegiatan belajar mengajar Ma'had Aly harus dilakukan secara berjenjang dan berkesinambungan. Dengan kata lain, Ma'had Aly harus menerima mahasantri setiap tahun dan menyelenggarakan program kajian-kajian keilmuan dengan bobot akedemik minimal 140 SKS. Mengikuti Keputusan Dirjen tersebut, maka sejak tahun ajaran 2009/2010 program Ma'had Aly As'adiyah Sengkang mulai menyelenggarakan pendidikan Ma'had Aly secara formal yang

\footnotetext{
${ }^{44}$ Wawancara dengan Dr. Huzaimah (Alumni Haiatut Takaful kelas Sengkang dan Kepala Kantor Kementerian Agama Kabupaten Soppeng) di Kantor Kemenag Kabupaten Soppeng pada tanggal 26 September 2016.

${ }^{45}$ Wawancara Muhammad Waris (Imam Masjid Jami Sengkang) di Kantor Kemenag Kabupaten Wajo pada tanggal 2 Oktober 2016.
} 
disetarakan dengan program sarjana yang ditandai dengan penerimaan mahasantri tiap tahun dan perpanjangan masa pendidikan dari tiga tahun menjadi empat tahun (diramu dari sambutan syaikhul Mudir Ma'had Aly Sengang, Rafi Yunus Martan dan wawancara dengan Muhiddin Thahir). ${ }^{46}$

Pasca ditandatanganinya PMA No. 71 Tahun 2015, dimana Ma'had Aly As'adiyah Sengkang salah satu dari 13 Ma'had Aly yang sudah diakui di Indonesia, maka pada tahun 2016 telah menerima sebanyak 50 mahasantri (Sembilan di antaranya putri). Program khusus Ma'had Aly dipusatkan di Kampus IV Jalan Andi Unru Jalur Dua Ujung Baru Kecamatan Tanasitolo. Penyelenggaraan Program Ma'had Aly Pondok Pesantren As'adiyah Sengkang telah diresmikan oleh Dirjen Pendidikan Islam Kemenag RI, Kamaruddin Amin atas nama Menteri Agama pada tanggal 12 Agustus 2016 di Kabupaten Wajo.

Pola pengkaderan ulama yang diselenggarakan oleh Ma'had Aly Sengkang tidak memiliki pola yang paten, ia mengikuti keinginan pengelola berdasarkan kebutuhan masyarakat pada saat itu. Program Haiatut Takaful, misalnya, mewajibkan kepada mahasantrinya untuk menghafal delapan juz Al Qur'an. Berbeda dengan Ma'had Aly yang diselenggarakan As'adiyah secara Mandiri. Pada angkatan Awal Ma'had Aly As'adiyah mewajibkan juz 30 dan 29, serta surah Hamim sajdah dan surah Al Insan. Adapun Ma'had Aly yang sudah disetarakan dengan S1 diwajibkan menghafal 6 juz. Sangat berbeda lagi dengan Ma'had Aly yang baru diresmikan, mahasantri wajib menghafal 30 Juz Al-Qur'an. Demikian halnya dengan kurikulum. Sebelum PMA Nomor 71 Tahunn2015, kurikulum Ma'had Aly diramu oleh pengurus sesuai dengan kebutuhan masyarakat, namun program MA'had Aly yang baru, suka atau tidak harus mengikuti kurikulum yang ditetapkan oleh pemerintah.

Hal lain yang berbeda setelah dikeluarkannya regulasi Ma'had Aly adalah Kementerian Agama memiliki komitmen kuat membangun pusat-pusat unggulan ini. Dengan posisi ini, maka Ma'had Aly akan tetap ditempatkan sebagai lembaga khusus (khushushul-khushush) yang ada pada pesantren, sebagai lembaga kaderisasi ulama yang mumpuni dan berintegritas. Adapun ke-13 Ma'had Aly yang telah mengantongi izin pendirian dan nomor statistic, serta kekhususannya, yaitu:

\footnotetext{
${ }^{46}$ Wawancara Dr. Muhiddin Thahir (Pimpinan Ma'had Aly Pondok Pesantren Sengkang) di Kampus Ma'had Aly Sengkang pada tanggal 15 Oktober 2016.
} 
1) Ma'had Aly Saidus Shiddiqiyyah, Pondok Pesantren As-Shiddiqiyah Kebun Jeruk (DKI Jakarta) dengan program tahassuss (spesialisasi): Sejarah dan Peradaban Islam (Tarikh Islami wa Tsaqafatuhu),

2) Ma'had Aly Syekh Ibrahim al Jambi, Pondok Pesantren Al As'ad Kota Jambi, dengan program takhassus (spesialisasi): Fiqh dan Ushul Fiqh (Fiqh wa Ushuluhu),

3) Ma'had Aly Sumatera Thawalib Parabek, Pondok Pesantren Sumatera Thawalib Parabek, Agam (Sumatera Barat(,dengan program takhassus (spesialisasi): Fiqh dan Ushul Fiqh (Fiqh wa Ushuluhu),

4) Ma'had Aly MUDI Mesjid Raya, Pondok Pesantren Ma'hadul 'Ulum ad Diniyah al Islamiyah (MUDI) Mesjid Raya, Bireun (Aceh), dengan program takhassus (spesialisasi): Fiqh wa Ushul Fiqh (Fiqh wa Ushuluhu),

5) Ma'had Aly As'adiyah, Pondok Pesantren As'adiyah Sengkang (Sulawesi Selatan), dengan program takhassus (spesialisasi): Tafsir dan Ilmu Tafsir (Tafsir wa Ulumuhu),

6) Ma'had Aly Rasyidiyah Khalidiyah, Pondok Pesantreb Rasyidiyah Khalidiyah Amuntai (Kalimantan Selatan), dengan program takhassus (spesialisasi): Akidah dan Filsafat Islam (Aqidah wa Falsafatuhu),

7) Ma'had Aly Salafiyah Syafi'iyah, Pondok Pesantren Saafiyah Syafi'iyah Situbondo (Jawa Timur, dengan program takhassus (spesialisasi): Fiqh dan Ushul Fiqh (Fiqh wa Ushuluhu),

8) Ma'had Aly Hasyim Al Asy'ary, Pondok Pesantren Tebuireng Jombang (Jawa Timur), dengan program takhassus (spesialisasi): Hadits dan Ulmu Hadits (Hadits wa Ulumuhu),

9) Ma'had Aly at Tarmasi, Pondok Pesantreb Tremas (Jawa Timur), dengan program takhassus (spesialisasi): Fiqh san Ushul Fiqh (Fiqh wa Ushuluhu),

10) Ma'had Aly Pesantren Maslakul Huda fi Ushul al Fiqh, Pondok Pesantren Maslakuk Huda Kajen Pati (Jawa Tengah), dengan program takhassus (spesialisasi): Fiqh dan Ushul Fiqh (Fiqh wa Ushuluhu),

11) Ma'had Aly PP Iqna ath Thalibin, Pondok Pesantreb al Anwar Sarang Rembang (Jawa Tengah), dengan program takhassus (spesialisasi): Tasawuf dan Tarekat (Tasawwuf wa Thariqat), 
12) Ma'had Aly Al Hikamus Salafiyah, Pondok Pesantren Madrasah Hikamus Salafiyah (MHS) Cirebon (Jabar), dengan program takhasus: Fiqh dan Ushul Fiqh (Fiqh wa Ushuluhu), dan

13) Ma'had Aly Miftahul Huda, Pondok PesantrenManonjaya Ciamis (Jabar), dengan program takhasus: Aqidah dan FIlsafat Islam (Aqidah wa Falsafatuhu). ${ }^{47}$

Ada yang menarik dari ke-13 pondok pesantren yang sudah diberikan izin operasional menyelenggarakan Ma'had Aly, yakni setiap pondok pesantren penyelenggara Ma'had Aly memiliki kekhususan kajian. Adapun Ma'had Aly As'adiyah Sengkang, Wajo kajian kekhususannya adalah "Tafsir dan Ilmu Tafsir" (Tafsir wa Ulumuhu). Ini dimaksudkan untuk membangun keunggulan dengan integritas akademik yang tinggi, Kementerian Agama memastikan setiap Ma'had Aly hanya diberikan izin penyelenggaraan untuk satu Program Studi. Lebih dari itu, program studi dimaksud juga akan dikembangkan menjadi pusat kajian keilmuan ke-Islaman dan ke-pesantrenan secara sekaligus. Dengan demikian, Ma'had Aly adalah perguruan tinggi keagamaan Islam yang menyelenggarakan pendidikan akademik dalam bidang penguasaan ilmu agama Islam (tafaqquh fiddin) berbasis kitab kuning yang diselenggarakan oleh pondok pesantren. Kitab kuning yang dimaksud adalah kitab keislaman berbahasa Arab yang menjadi rujukan tradisi keilmuan Islam di pesantren. Adapun tujuan Ma'had Aly adalah menciptakan lulusan yang ahli dalam bidang ilmu agama Islam (mutafaqqih fiddin), dan mengembangkan ilmu agama Islam berbasis kitab kuning.

\section{Kesimpulan}

Program Khusus Pengkaderan Ulama di Pondok Pesantren (yang lebih dikenal dengan nama Ma'had Aly) mengalami pasang surut. Beberapa pesantren menyelenggarakan program ini, ada yang vakum dan ada pula yang berjalan terus dengan segala dinamikanya. Salah satu pesantren yang menyelenggarakan program khusus ini adalah Pondok Pesantren As'adiyah Sengkang. Pondok As'Asiyah Sengkang pernah melakukan Ma'had Aly yang tergabung dalam program sinergitas empat pondok Pesantren di Sulawesi Selatan (DDI Parepare, As'adiyah

\footnotetext{
${ }^{47}$ (http://www.nu.or.id/post/read/68634/inilah-13-ma'had-aly-yang-diresmikan- olehmenteri-agama diunduh tanggal 25 September 2016.
} 
Sengkang, Yasrib Soppeng, dan Ma'had Hadis Biru Bone) yang dikenal dengan nama Haiatut Takaful. Akan tetapi setelah Haiatut Takaful berbenti, Pondok Pesantren As'adiyah masih melakukan program khusus ini dengan nama Ma'had Aly As'adiyah Sengkang. Penyelenggaraan Ma'had Aly memiliki banyak pola, mulai dari rekrutmen mahasantri, sistem belajar, lama belajar, dan kurikulum yang digunakan, semua dilakukan sesuai dengan tuntutan zaman pada masanya.

Terselenggaranya Program Khusus Pengkaderan Ulama (Ma'had Aly) di Pondok Pesantren As'adiyah Sengkang dapat terlaksana karena keikhlasan para Ulama yang bergabung dalam wadah Organisasi As'adiyah untuk mencetak ulama di Sulawesi Selatan serta keinginan yang kuat menjadikan As'adiyah sebagai poros utama pengkaderan Ulama di Sulawesi Selatan. Akan tetapi Porgram Ma'had Aly As'adiyah Sengkang bukan tanpa kendala. Banyak kendala yang dihadapi, mulai dari ketersediaan sarana dan prasarana yang kurang memadai bila dibandingkan dengan perguruan tinggi yang sudah diakui oleh Pemerintah, minat santri yang memilih Ma'had Aly masih sangat kurang, termasuk ketersediaan Pembina dengan latar belakang yang masih dirasakan kurang.

Dukungan pemerintah daerah dalam perjalanan pogram Ma'had Aly sangat tergantung pada bagaimana harmonis tidaknya antara penyelenggara Ma'had Aly dengan Pemerintah Daerah. Adapun pemerintah Pusat (dalam hal ini Kemenag RI), belum bisa diharapkan secara maksimal karena belum adanya regulasi yang memayungi. Akan tetapi dengan terbitnya PMA nomor 71 Tahun 2015, maka Ma'had Aly sudah disejajarkan dengan Perguruan Tinggi Agama.

\section{Daftar Pustaka}

Ahmad, Abd. Kadir. 2008. Ulama Bugis. Makassar: Indobis.

Alam, Sumange. 1982. Masuknya Islam di Wajo. Sengkang: Kantor Departemen Pendidikan dan Kebudayaan Kabupaten Wajo (Hasil Penelitian, belum terbit).

Ali, Fachri dan Bachtiar Effendy. 1986: Merambah Jalan Baru Islam. Bandung: Mizan.

Arif, Fahmi. 2003. K.H. Muhammad As'ad Al Bugisi, dalam Mastuki HS dan M. Ishom El Saha (eds). Intelektualisme Pesantren Potret 
Tokoh dan Cakrawala Pemikiran si Era Perkembangan Pesantren. Jakarta: Diva Pustaka.

Bisfain. 1984. K.H. Muhammad As'ad: Peranannya Dalam dakwah di Daerah Wajo (Skripsi). Ujungpandang: Fakultas Ushuluddin IAIN Alauddin Makassar.

Bone, Abd. Aziz al. 1986. Lembaga Pendidikan Islam di Sulawesi Selatan (Studi Kasus di Perguruan As'adiyah Sengkang. Jakarta: Yayasan ilmu-Ilmu Sosial.

Bosra, Mustari. 2006. Tuan Guru, Anrong Guru dan Daeng Guru: Gerakan Islam di Sulawesi Selatan 1014-1942. Makassar: La Galigo Press.

Bruinessen Martin van. 1998. Muhammad As'ad Bugis (Wajo, South Sulawesi, Indonesia 1907-1953), dalam Dictionnaire Biographigue des Savants et Grande Figures du Munde Musulman Periperique, du XIXe siècle a nos jours, Fasc, No. 2. Faris: CNRS-EHESS.

Damopolii, Muljono. 2005. Pembaruan Pendidikan Islam di Makassar (Studi Kasus Pesantren Modern Pendidikan Al Qur'an IMMIM Tamalanrea Makassar. Disertasi (belum terbit). Jakarta: Program Pascasarjana UIN Syarif Hidayatullah Jakarta.

Dewan Redaksi Esiklopedi Islam. 1994. Ensiklopedi Islam, jilid V. Jakarta: Ikhtiar Baru Van Hoeve.

Dhofier, Zamakhsyari. 1994. Tradisi Pesantren: Studi Tentang Pandangan Kyai. Jakarta:LP3ES.

Hafid, Abdul Karim. 1997. K.H. Muhammad As'ad dan Peraannnya Terhadap Pemurnian Aqidah Islamiyah di Wajo. Sengkang: Sekolah Tinggi Islam As'adiyah Sengkang.

Halim, Abdul Rahman. 2008. Kebijakan dan Partisipasi Masyarakat (Studi Terhadap Perspektif Pembinaan Madrasah Swasta di Sulawesi Selatan (Disertasi, belum terbit). Yogyakarta: Pascasarjana UIN Sunan Kalijaga Yogyakarta.

Halim, Wahyuddin. 2015. As'adiyah Traditions: The Construcion and Reproduction of Religious Authority in Contemprary South Sulawesi (Disertasi, belum terbit). Australia: Australian National University.

Hamid, Abu. 1983. Sistem Pendidikan Madrasah dan Pesantren di Sulawesi Selatan, dalam Taufik Abdullah, Agama dan Perubahan Sosial, Jakarta: Rajawali Press . 
Pola Pengkaderan Vlama di Sulawesi Selatan (Studi pada Program Ma'had Aly Pondok Pesantren As'adiyah Sengkang Kabupaten Wajo)

Hamka, Zainuddin. 2009. Corak Pemikiran Keagamaan Gurutta H. Muh. As'ad Al Bugisi. Jakarta: Departemen Agama RI Badan Litbang dan Diklat Pulitbang Lektur dan Khazanah Lektur Keagamaan.

Helmy, Masdar. Tth. Dakwah Islam Alam Pembangunan. Semarang: Toha Putra.

http://www.nu.or.id/post/read/68634/inilah-13-ma'had-aly-yangdiresmikan-oleh-menteri-agama diunduh tanggal 25 September 2016.

https://www.nu.or.id/post/read/68643/ mahad - aly-sebagai-pusatunggulan, diunduh tanggal 25 September 2016

Ismail, Daud. 1989. Al Ta'rifu bi al 'alimi al 'Allamah al Haji Muhammad As'ad al Bugisy. Ujungpandang: Bintang Selatan.

Louis al-Ma'luf.1980. al-Munjid fi al-Lugati wa al-A'lam. Cet. XXXVIII; Dar al-Masyriq: Libanon.

Malik, Abd. 2001. Studi Tentang Efektifitas Pendidikan Kader Ulama (PKU) Terhadap Kaderisasi Ulama di Sulawesi selatan (tesis belum terbit). Makassar: Program Pascasarjana Universitas Muslim Indonesia.

Manguluan, Hamzah. 1989. Ana wa Syaekhi (Riwayatku dan Mahaguruku). Sengkang: ttp.

Mappangara, Suradi dan Irwan Abbas. 2003. Sejarah Islam di Sulawesi Selatan. Makassar: Lamacca Press.

Maratan, Muh. Yunus 1978. Sejarah Singkat Berdirinya Perguruan Madrasah As'adiyah, dalam majalah Bulanan: Safari Dakwah, No. 15 Tahun II.

Mastuhu. 1994. Dinamika Sistem Pendidikan Pesantren; Suatu Kajian Tentang Unsur dan Nilai Sistem Pendidikan Pesantren. Jakarta: INIS.

Mattulada. 1983. Islam di Sulawesi Selatan, dalam Taufik Abdullah (ed). Agama dan Perubahan Sosial. Jakarta: Rajawali.

Muchsin, Agus. 2014. Konstruksi Kaderisasi Ulama Pondok Pesantren As'adiyah Sengkang dan Pondok Pesantren Darud Dakwah wal Irsyad Mangkoso: Tinjauan Terhadap Manhaj Fikih Pesanttren (disertasi, belum Terbit). Makassar: Program Pascasarjana UIN Alauddin Makassar.

Mukhlis. 1987. Agama dan Realitas Sosial. Ujungpandang: Lephas. Munawwir, A.W. 1997. Kamus al-Munawwir Arab-Indonesia Terlengkap. Cet. XIV; Surabaya: Pustaka Progressif. 
Pasanreseng, Muh. Yunus. 1992. Sejarah Lahir dan Prtumbuhan Pondok Pesantren As'adiyah Sengkang. Sengkang: Pengurus Besar As'adiyah.

Pasanreseng, Muh. Yunus. 2015. Efektifitas Dakwah Pondok Pesantren As'adiyah (Disertasi, belum terbit). Makassar: Pascasarjana UIN Alauddin Makassar.

Pimpinan Pusat As'adiyah. 1982: Buku Setengah Abd As'adiyah 19301980. Sengkang: Pesantren As'adiyah.

Rahman, Ahmad (ed). 2010. Inventarisasi Karya Ulama di Lembaga Pendidikan Keagamaan. Jakarta: Puslitbang nLektur Keagamaan Balitbang dan Diklat Keagamaan Kementerian Agama RI.

Rama, Bahaking. 2000. Pembaharuan Pendidikan Pesantren As'adiyah Sengkang-Wajo Sulawesi Sealatan. Disertasi. Jakarta: Program Pascasarjana IAIN Syarif Hidayatullah Jakarta.

Safwan, Mardanas dan Sutrisno Kutoyo. 1981. Sejarah Pendidikan Daerah Sulawesi Selatan. Ujungpandang: Proyek Inventarisasi dan Dokumentasi.

Shihab, Quraish. 2007. Ensiklopedia al-Qur'an: Kajian Kosakata. Jilid III. Cet. I; Jakarta: Lentera Hati.

Sugiyono. 2010. Metode Penelitian Pendidikan (Pendekatan Kualitatif, Kuantitatif, dan $R \& D$. Bandung: Alfabeta.

Surur, M. Bunyamin Yusuf. 2011. K.H. As'ad bin Abd. Rasyid al Bugisy:Perintis Ulama Huffazh di Sulawesi Selatan (1907-1952), dalam Muhammad Shohib dan M. Bunyamin Surur (eds). Para Penjaga Al Qur'an: Biografi Huffaz Al-Qur'an di Nusantara. Jakarta: Lanjnah Pentashihan Mushaf Al Qur'an Badan Litbang dan Diklat Kementerian Agama RI.

Tamrin, M. Tth. Metodologi Dakwah. Jakarta: YPI Ibnu Sina.

Tim Penyusun Kamus Pusat Pembinaan dan Pengembangan Bahasa Departemen Pendidikan dan Kebudayaan. 1990. Kamus Besar Bahasa Indonesia. Cet. III. Jakarta: Balai Pustaka.

Walinga, Muh. Hatta. 1981. Kiyai Haji Muhammad As'ad Hidup dan Perjuangannya (Skripsi). Ujungpandang: Fakultas Adab IAIN Alauddin Makassar.

Weber, Max. 1964. The Sosiology of Religion. Boston: Beacon Press. Ziemek, Manfred. 1986. Pesantren dalam Perubahan Sosial. Jakarta: P3M. 